\title{
Ni-W 合金めっきの皮膜クラックに及ぼすめっき内部応力の影響
}

\author{
石井一也 ${ }^{\mathrm{a},{ }^{*}}$, 高山 透 $^{\mathrm{b}}$, 土井教史 ${ }^{\mathrm{b}}$, 木本雅也 ${ }^{\mathrm{a}}$, 林 秀考 ${ }^{\mathrm{c}}$, 岸本 昭 $^{\mathrm{c}}$ \\ a 新日鐵住金侏 鉄鋼研究所 ( $\bar{T} 660-0891$ 兵庫県尼崎市扶桑町 1-8) \\ b 新日鐵住金(侏) 先端技術研究所 ( $\bar{T} 660-0891$ 兵庫県尼崎市扶桑町 1-8) \\ c 岡山大学大学院自然科学研究科 (⿳亠口冖 700-8530 岡山県岡山市北区津島中 3-1-1)
}

\section{Influence of Internal Stress on Plating Crack in Ni-W Alloy Electroplating}

\section{Kazuya ISHII ${ }^{a *}$, Toru TAKAYAMA ${ }^{\mathrm{b}}$, Takashi DOI ${ }^{\mathrm{b}}$, Masanari KIMOTO ${ }^{\mathrm{a}}$, Hidetaka HAYASHI ${ }^{\mathrm{c}}$ and Akira KISHIMOTO}

\footnotetext{
${ }^{a}$ Nippon Steel \& Sumitomo Metal Corporation, Steel Research Laboratories(1-8, Fuso-cho, Amagasaki-shi, Hyogo 660-0891)

${ }^{\mathrm{b}}$ Nippon Steel \& Sumitomo Metal Corporation, Advanced Technology Research Laboratories(1-8, Fuso-cho, Amagasaki-shi, Hyogo 660-0891)

${ }^{c}$ Graduate School of Science and Technology, Okayama University(3-1-1, Tsushima-Naka, Kita-ku, Okayama-shi, Okayama 700-8530)
}

\begin{abstract}
$\mathrm{Ni}-\mathrm{W}$ alloy plating has been considered for application to various industrial fields as a substitute for hard $\mathrm{Cr}$ plating. However, by plating conditions, the plating crack on Ni-W alloy film might occur and cause difficulties in industrial use. In this study, we elucidated the plating crack behavior of $\mathrm{Ni}-\mathrm{W}$ alloy films with various $\mathrm{W}$ contents. We also investigated the influence of the internal stress of $\mathrm{Ni}-\mathrm{W}$ alloy film on the plating cracks. Results show that the number of the plating cracks changed by $\mathrm{W}$ content in the range of $27.3-51 \mathrm{wt} \% \mathrm{~W}$. At approximately 40 $\mathrm{wt} \% \mathrm{~W}$, plating cracks did not occur. Moreover, the change of the internal stress of Ni-W alloy film in the range of $30-46 \mathrm{wt} \% \mathrm{~W}$ showed a convex-downward curve against the $\mathrm{W}$ content, which indicated the least internal stress in approximately $40 \mathrm{wt} \% \mathrm{~W}$. Furthermore, the influence of the misfit between the Ni-W alloy film and that substrate was small, which suggests that the internal stress of the film itself changed. Therefore, the internal stress was regarded as a direct factor affecting the plating crack. Furthermore, from results of X-ray diffraction patterns of Ni-W alloy films with various $\mathrm{W}$ contents, the change of the internal stress was inferred to have resulted from the change of the crystalline state.
\end{abstract}

Keywords : Ni-W Alloy Plating, Plating Crack, Internal Stress, Crystalline State

\section{1. 緒言}

$\mathrm{Ni}-\mathrm{W}$ 合金めつきは, 耐摩耗性 ${ }^{1) \sim 3)}$, 耐酸性 ${ }^{4), 5)}$ および耐熱 性 ${ }^{6)}$ などの諸特性を有する。さらに, 高い皮膜硬度 ${ }^{5), 7), 8)}$ も 安定して得られることから, 硬質 $\mathrm{Cr}$ めっきの代替めっきと して, 主にガラス成型用金型, ロール表面材料, 自動車摺動

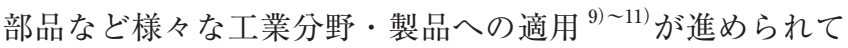
いる。しかしながら, Ni-W 合金めっきは, めっき浴および 電解条件によって, めっき皮膜にクラックの生じる場合があ る $^{11), 12)}$ 。めっき皮膜にクラックが生じると，例えばクラッ クから腐食因子等が浸入し, 下地材料を腐食させる, あるい はそれに伴ってめっき剥離が生じるなどして, 諸性能を劣化 させる可能性がある。

めっき皮膜のクラック発生要因として, めっき材への熱応力 の影響, すなわち環境温度変化がもたらすめっき皮膜と基材と の膨張・収縮差による影響が考えられるが, 環境温度変化を考 慮しない場合には, 高いめっき内部応力が主因と考えられる。 めっき内部応力の発現理由には，これまでに諸説 ${ }^{13)}$ １6) がある。 例えば, 共析した水素の $\mathrm{Cr}$ 格子からの離脱説 ${ }^{13)}$, 結晶合体 説 ${ }^{14)}$ が考えられている。この他, 過剩エネルギー説 ${ }^{15)}$ および 格子欠陷説 ${ }^{16)}$ なども提案されている。 Ni-W 合金めっきは, めっ

\footnotetext{
*E-mail : ishii.34z.kazuya@jp.nssmc.com
}

き電流効率が $50 \sim 60 \%$ と低く，且つ $\mathrm{Ni}, \mathrm{W}$ 共に放電の交換 電流密度が小さく，金属の電析表面での拡散速度も小さいため, 結晶成長よりも核生成優先となり易い ${ }^{17)}$ 。従って, 上述の共析 水素離脱説および結晶合体説に従う挙動により, めっき引っ張 り応力の生じ易いめっき種であることは推測される。

本論文では, 工業利用上問題となり得る Ni-W 合金めっき 皮膜のクラックに関し, W 含有量によるクラック発生の挙 動把握, さらにその発生要因と考えられるめっき内部応力の 影響について調査した結果を述べる。

\section{2. 実験方法}

\section{1 めっき電解浴組成および電解条件}

めつき基板には極低炭冷延鋼板を用い, 溶剤脱脂後, 電解 脱脂 ( $5 \mathrm{wt} \% \mathrm{NaOH}, 50{ }^{\circ} \mathrm{C}$, 陰極電解 : $4 \mathrm{~A} \cdot \mathrm{dm}^{-2}, 10 \mathrm{~s}$ 電解) お よび酸洗 $\left(4 \mathrm{vol} \% \mathrm{H}_{2} \mathrm{SO}_{4}, 50{ }^{\circ} \mathrm{C}, 5 \mathrm{~s}\right.$ 浸漬)の前処理の後, 電 気 Ni-W 合金めっきに供した。尚, 脱脂および酸洗等の薬液 調製には, 全て市販特級試薬(液体試薬の $\mathrm{H}_{2} \mathrm{SO}_{4}$ および $\mathrm{HCl}$ は，純度 $97 \%$ および $35 \%$ 液を使用）を使用した。めっきは, 図 1 に示すフローセルにより, めっき液を液流速 $1 \mathrm{~m} \cdot \mathrm{s}^{-1}$ の 条件で循環させながら行なった。めっき電解浴組成および電 解条件を表 1 に示す。 Ni-W 合金めっき電解浴は, 市販特級 試薬の硫酸ニッケル，タングステン酸二ナトリウムおよびク エン酸三アンモニウムをイオン交換水に所定量溶解させて作 
製した。錯化㓮として, 電流効率確保の観点 ${ }^{18)}$ から, クエ ン酸三アンモニウムを用い, 浴中金属成分である $\mathrm{Ni}$ イオン とタングステン酸イオン $\left(\mathrm{WO}_{4}{ }^{2-}\right)$ は, 各々クエン酸と $1: 1$ で錯形成 ${ }^{19)}$ することから, 金属塩添加量は合計で錯化剂と 同量とした。めっき浴の $\mathrm{pH}$ は $\mathrm{H}_{2} \mathrm{SO}_{4}$ および $\mathrm{NaOH}$ を用い, pH 5.0 に調整した。浴中の全金属塩濃度は $0.6 \mathrm{~mol} \cdot \mathrm{dm}^{-3}$ で 一定とし，全金属塩濃度に対するタングステン酸二ナトリウ 么濃度の比を適宜変更することにより, 種々のタングステン 含有量の Ni-W 合金めっきを作製した。

\section{2 めっき内部応力の測定}

めっき皮膜の内部応力の測定には, スパイラルコントラク トメーター(株山本鍍金試験器製)を用いた。基材には螺旋帯 状に加工したSUS304 用い, 脱脂 $\left(5 \mathrm{wt} \% \mathrm{NaOH}, 50{ }^{\circ} \mathrm{C}\right.$, 陰 極電解 : $4 \mathrm{~A} \cdot \mathrm{dm}^{-2}$, $30 \mathrm{~s}$ 電解) および酸洗 $(10 \mathrm{vol} \% \mathrm{HCl}$, 常温, $10 \mathrm{~s}$ 浸漬)の前処理を行った後, めっき密着性確保のために ウッド浴 ${ }^{20)}\left(\mathrm{NiCl}_{2} 240 \mathrm{~g} \cdot \mathrm{dm}^{-3}, \mathrm{HCl} 125 \mathrm{~mL} \cdot \mathrm{dm}^{-3}\right)$ による $\mathrm{Ni}$ ストライク処理 $\left(5 \mathrm{~A} \cdot \mathrm{dm}^{-2}, 30 \mathrm{~s}\right.$ 電解)を施した。この後, 全 金属塩濃度に対するタングステン酸二ナトリウム濃度の比を 適宜変更した各 Ni-W 合金めっき浴により，めっき電解時間 が 25 min. となるまで連続してめっきを行い，その際のめっ き内部応力変化を追跡した。尚, 電流密度は $20 \mathrm{~A} \cdot \mathrm{dm}^{-2}$ 一 定の条件下で実験を行った。めっき皮膜の内部応力は, Brenner-Senderoffの導出式 ${ }^{21,22)}$ に従い，螺旋帯状基材への めっきに伴う回転変位により算出し，正をめっき引張り応力，

(a) Side view

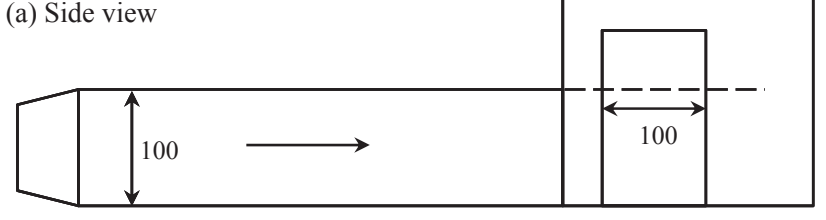

(b) Top view

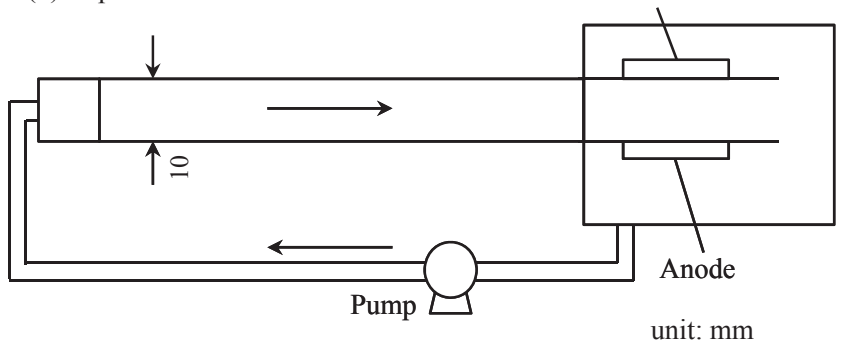

Fig. 1 Experimental plating equipment of solution flow type cell.

Table 1 Bath composition and plating condition for Ni-W alloy plating.

\begin{tabular}{ll}
\hline $\begin{array}{l}\text { Composion of solution } \\
\text { Nickel sulfate hexahydrate }\end{array}$ & $0.18-0.3 \mathrm{~mol} \cdot \mathrm{dm}^{-3}$ \\
Sodium tungstate dihydrate & $0.3-0.42 \mathrm{~mol} \cdot \mathrm{dm}^{-3}$ \\
{$\left[\mathrm{WO}_{4}{ }^{2-}\right] /\left(\left[\mathrm{Ni}^{2+}\right]+\left[\mathrm{WO}_{4}{ }^{2-}\right]\right)$} & $0.5-0.7$ \\
Triammonium citrate & $0.6 \mathrm{~mol} \cdot \mathrm{dm}^{-3}$ \\
\hline Substrate & \\
Al-killed cold rolled steel sheet & \\
\hline Plating condition & \\
Current density & $5 \sim 30 \mathrm{~A} \cdot \mathrm{dm}^{-2}$ \\
$\mathrm{pH}$ & 5.0 \\
Bath temperature & $60{ }^{\circ} \mathrm{C}$ \\
Solution flow rate & $1 \mathrm{~m} \cdot \mathrm{sec}^{-1}$ \\
\hline
\end{tabular}

負をめっき圧縮応力として，数值化した。

\section{3 めっき皮膜の物性評価}

得られた Ni-W 合金めっき皮膜に対し, Ni およびW のめっ き含有量は，めっき表面からの SEM/EDX 分析により求めた。 めっき皮膜のクラック状況の把握には, めっき皮膜の断面埋 込み試料を作製し, SEM により観察した。また, めっきクラッ ク数は, めっき表面からの光学顕微鏡観察視野内での長さ $500 \mu \mathrm{m}$ の線分を横切るクラック数(視野数 2 , 線分数は各視 野毎に 3 本)を計数し，これを $1 \mathrm{~cm}$ 当りに換算した数と定義 し, 数值化した。さらに, めっきの結晶性は, 各 $\mathrm{W}$ 含有量 に拈けるめっき材の Co 管球による X 線回折図形を求め, 評 価した。

\section{3. 結果および考察}

\section{3. $1 \mathrm{~W}$ 含有量とめつき皮膜のクラックとの関係}

$\mathrm{W}$ 含有量を変化させた Ni-W 合金めっき皮膜の断面 SEM 観察像を図 2 に示す。めっき皮膜のクラック状態は $\mathrm{W}$ 含有 量によって変化し, W 含有量が $40 \mathrm{wt} \%$ 前後 $(39.5$ および $42.4 \mathrm{wt} \%)$ ではクラックは認められなかった。また, 図 3 には,

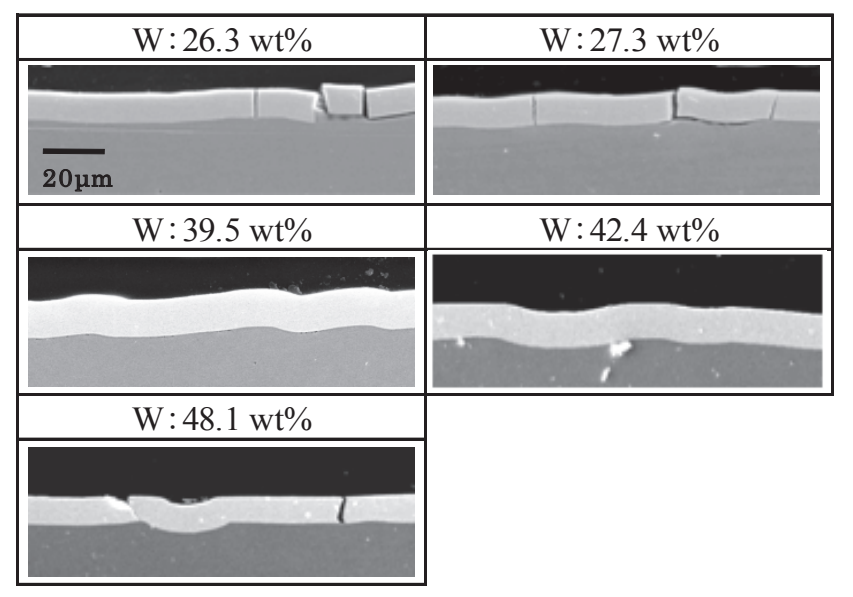

Fig. 2 Scanning electron micrograph of a cross section of Ni-W film with various $\mathrm{W}$ content.

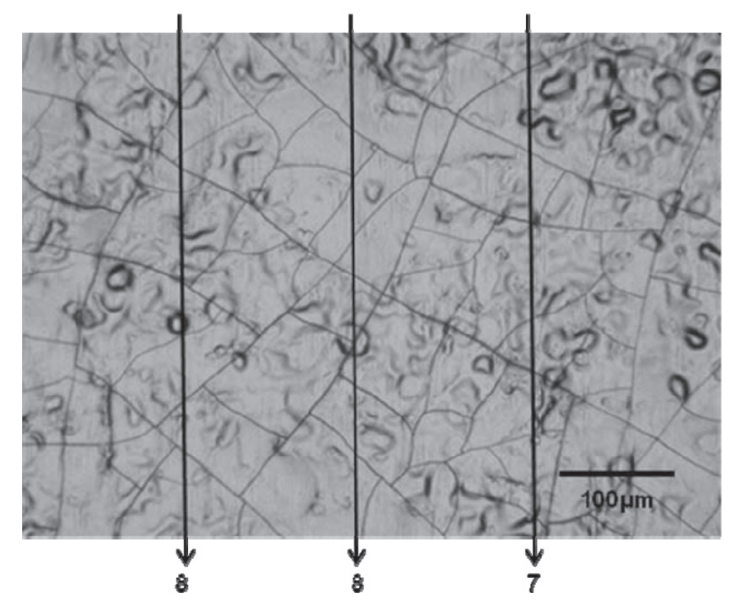

Fig. 3 An example of calculation method of the number of surface crack. (Sample: $27.3 \mathrm{wt} \% \mathrm{~W}$ )

The number of crack : $(8+8+7) / 3 * 20=153 \cdot \mathrm{cm}^{-1}$ 
$27.3 \mathrm{wt} \% \mathrm{~W}$ のめっき材について, めっき表面の光学顕微鏡観 察によりクラック数を計数した一例を示す。本例では, クラッ ク数はおよそ $150 \cdot \mathrm{cm}^{-1}$ と計数された。これと同様の方法に より, $27.3 \mathrm{wt} \%$ 〜 $51 \mathrm{wt} \% \mathrm{~W}$ のめっき材についてクラック数 を求め, W 含有量で整理した結果を図 4 に示す。W 含有量 に対するクラック数の変化は, $\mathrm{W}$ 含有量の増加と共に減少し, $40 \mathrm{wt} \% \mathrm{~W}$ 前後 $(38 \mathrm{wt} \%$ 〜 $42 \mathrm{wt} \% \mathrm{~W})$ では発生せず，その後再 び増加する下に凸形状の変化を示した。

$\mathrm{Ni}-\mathrm{W}$ 合金めっき皮膜に生じるクラックについて, Matsuda $ら^{11)}$ は, クラックとめっき内部応力との関係を調査し, W 含有量が $42 \mathrm{wt} \% \mathrm{~W}$ 以上ではめっき引張り応力が著しく減少 しクラックが抑制されるが， $34 \mathrm{wt} \% \mathrm{~W}$ までは高いめっき引 張り応力が働き, クラック発生の原因となることを推定して いる。筆者らの得た結果は，本知見の傾向とほほ符合するも のであるが， $40 \mathrm{wt} \% \mathrm{~W}$ よりも大きい W 含有量範囲で再びク ラック数の増加することを示した点では異なっている。また, Alimadadi $~^{23)}$ は, W 含有量の変化に伴うめっき皮膜表面の クラック密度の変化を調査し, 図4の結果と同様に,

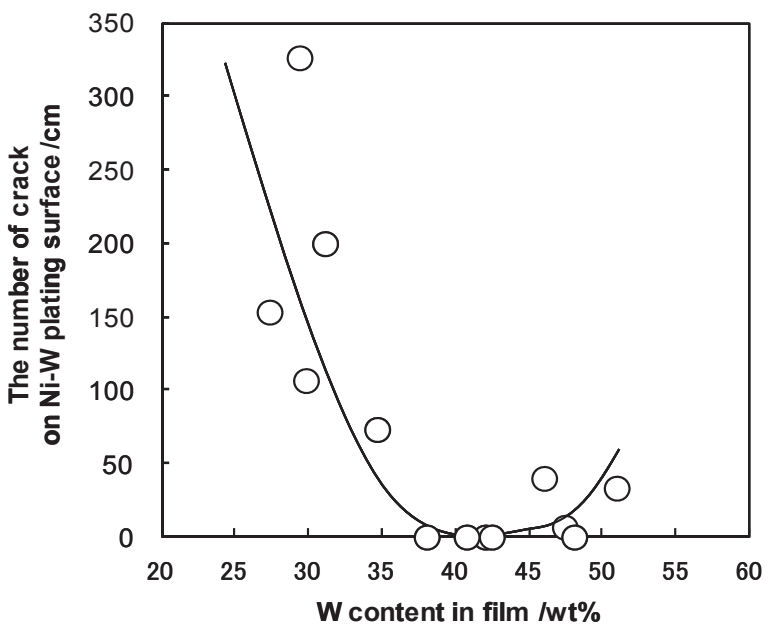

Fig. 4 Relationship between the number of crack on Ni-W alloy plating surface and $\mathrm{W}$ content in film.

(film thickness:10.2-14.3 $\mu \mathrm{m}$ )

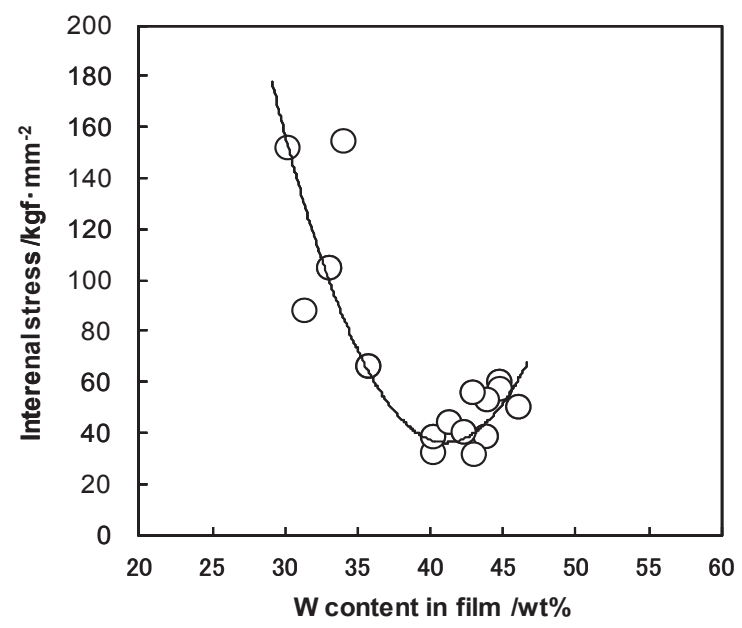

Fig. 5 Relationship between internal stress and W content in $\mathrm{Ni}-\mathrm{W}$ alloy film (film thickness; $10 \mu \mathrm{m}$ ).
$40 \mathrm{wt} \% \mathrm{~W}$ 前後でのクラック密度の減少を認めている。クラッ ク発生については共析水素の脱離に伴うめっき引張り応力の 上昇によると推定しているが, $\mathrm{W}$ 含有量とめっき内部応力 との関係については詳細に言及していない。そこで，このよ うなめっき皮膜のクラック発生の直接的な要因と考えられる めっき内部応力について, W 含有量との関係ならびにクラッ クとの関係を，以下調査した。

\section{3. $2 \mathrm{~W}$ 含有量とめっき内部応力との関係}

$\mathrm{Ni}-\mathrm{W}$ 合金めっき皮膜のクラック発生要因と考えられる めっき内部応力について, $\mathrm{W}$ 含有量との関係を, スパイラ ルコントラクトメーターを用いた系統的な実験により求めた。 結果を図 5 に示す。W 含有量は，めっき浴条件の変更により, 30〜 46 wt \% W 範囲で変化させたが，めっき内部応力は全 て正值を示し, めっき引張り応力として検出された。また, $\mathrm{W}$ 含有量に対するめっき内部応力の変化は, 下に凸形状の 変化を示し, $\mathrm{W}$ 含有量が $40 \mathrm{wt} \% \mathrm{~W}$ 前後で最小のめっき内部 応力を示した。これらの変化は W 含有量に対するクラック 数の変化 (図 4) と良く一致し, めっき内部応力の高い場合に クラックの発生していることが分かる。さらに，めっき内部 応力がクラックの原因であると仮定すると, 図 5 の結果から, めっき皮膜のクラックの発生が認められなかった $40 \mathrm{wt} \% \mathrm{~W}$ 前後 $(38 \mathrm{wt} \%$ ～ $42.4 \mathrm{wt} \% \mathrm{~W})$ でのめっき内部応力は 40 $45 \mathrm{kgf} \cdot \mathrm{mm}^{-2}$ を示し, この応力值がクラック発生の臨界の内 部応力であることも示唆された。

$\mathrm{W}$ 含有量によるめっき内部応力の差異を明確にするために, 各 $\mathrm{W}$ 含有量のめっき形成過程でのめっき内部応力変化を調べ

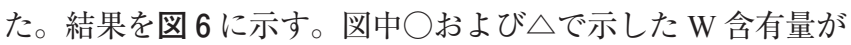
$40 \mathrm{wt} \% \mathrm{~W}$ までの Ni-W 合金めっきにおいて, めっき内部応力 はめっき形成初期から高い結果を示した。本めっき材は, 下 地処理に Ni ストライクめっきを施しているため, 金属 $\mathrm{Ni}$ 上 に Ni-W 合金めっきが析出している。金属 Ni は fcc 構造であり, $\mathrm{Ni}-\mathrm{W}$ 合金めっきは(後述のように) fcc 構造の $\mathrm{Ni}$ 結晶に W 原 子が置換固溶した置換型固溶体と考えられる。従って, 観測

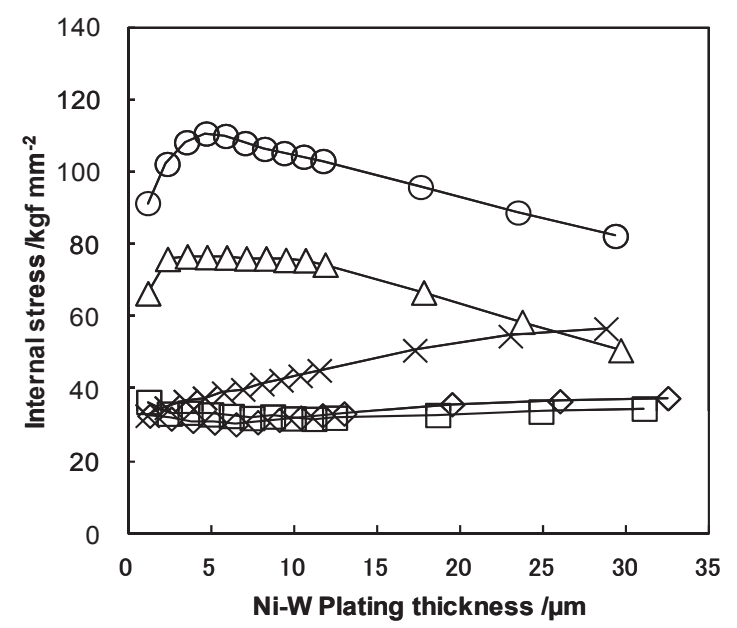

Fig. 6 Change of internal stress during electrodeposition of $\mathrm{Ni}-\mathrm{W}$ alloy film with various $\mathrm{W}$ content. (Current density for plating : $20 \mathrm{~A} \cdot \mathrm{dm}^{-2}$ )

$\bigcirc: 33.0 \mathrm{wt} \% \mathrm{~W}, \triangle: 35.7 \mathrm{wt} \% \mathrm{~W}, \square: 40.1 \mathrm{wt} \% \mathrm{~W}$, $\diamond: 42.9 \mathrm{wt} \% \mathrm{~W}, \quad \times: 46.0 \mathrm{wt} \% \mathrm{~W}$ 
されためっき形成初期からの高いめっき内部応力は, 下地と の不整合, すなわちミスフィットの影響 ${ }^{24)}$ は小さく, めっき 皮膜自体の応力が検出されていると考えられる。また, 図中 口および〉で示した W 含有量が $40 \mathrm{wt} \% \mathrm{~W}$ 前後 $(40.1 \mathrm{wt} \% \mathrm{~W}$ お よび $42.9 \mathrm{wt} \% \mathrm{~W})$ の Ni-W 合金めっきにおいては，いずれも めっき初期から低いめっき内部応力を示した。さらに, W 含 有量が $46 \mathrm{wt} \% \mathrm{~W}$ の $\mathrm{Ni}-\mathrm{W}$ 合金めっきでは, $40 \mathrm{wt} \% \mathrm{~W}$ 前後のそ れに比較し，高いめっき内部応力を示した。

このように，本実験によるW 含有量範囲において， Ni-W 合金めっきのめっき内部応力は, 全てめっき引張り応力が検 出され, $\mathrm{W}$ 含有量に応じて大きく変化した。下地とのミス フィットの影響は小さく, W 含有量の変化に伴って, めっ き皮膜自体のめっき内部応力が変化しているものと考えられ た。次節では, これらの $\mathrm{W}$ 含有量による内部応力変化の作 用因子として, めっき皮膜の結晶性変化に着目し, めっき内 部応力への影響を述べる。

\section{3. $3 \mathrm{~W}$ 含有量によるめっき皮膜の結晶性変化}

$\mathrm{W}$ 含有量を変化させたときの Ni-W 合金めっき皮膜の結晶 性を, 図 7 に示す X 線回折図形により評価した。W 含有量 が $27 \mathrm{wt} \% \mathrm{~W}, 30 \mathrm{wt} \% \mathrm{~W}$ のっき皮膜は, シャープな $\mathrm{Ni}$ (111) ピークを示し, Niの結晶質のめっき皮膜と判断される。こ れよりも W 含有量の高いめっき皮膜では, 徐々にブロード な回折図形へと変化した。 $45 \mathrm{wt} \% \mathrm{~W}$ および $51 \mathrm{wt} \% \mathrm{~W}$ のつ き皮膜では, Ni (200), (220)のピークは消失し, Ni 結晶の 微細化, さらには非晶質へと移行していることが推察される。 Itoh ${ }^{25)}$ は, Ni-W 合金めっき膜の微細構造と熱平衡状態図 との関係を詳細に調査し, 常温での $\mathrm{W}$ 固溶限が $31 \mathrm{wt} \% \mathrm{~W}$ 程 度であることから，W 含有量がそれ以上の $43.5 \mathrm{wt} \% \mathrm{~W}$ まで のめっき皮膜は, W の過飽和固溶体(準安定相)であること, および約 $47 \mathrm{wt} \% \mathrm{~W}$ 以上では非晶質の皮膜であることを示し た。さらに, Kimoto ら ${ }^{26)}$ は, W が過飽和となる $31 \mathrm{wt} \% \mathrm{~W}$ 程度から $40 \mathrm{wt} \% \mathrm{~W}$ 前後の W 含有量範囲において, Ni-W 合 金めっきが結晶質と非晶質との混相皮膜であり, $\mathrm{W}$ 含有量 の増加に伴い, 非晶質の体積比率が大きくなることを示した。 これらが示す皮膜結晶性の変化は, 定性的にではあるが,

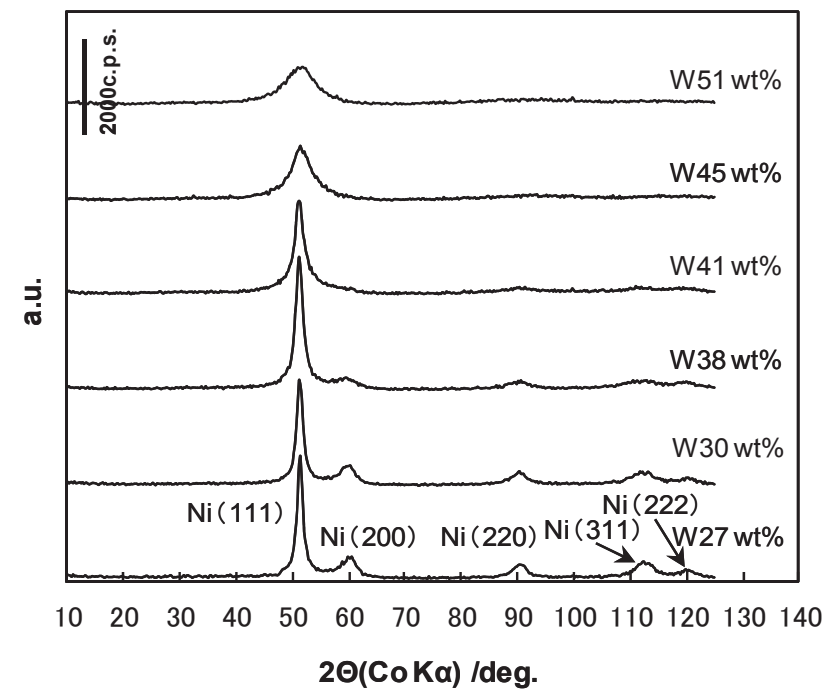

Fig. 7 X-ray diffraction profile of Ni-W alloy film with various $\mathrm{W}$ content.
図 7 の X 線回折図形の変化にも表れており, Ni-W 合金めっ きは, $\mathrm{W}$ 含有量の増加に伴って, 結晶質の皮膜から非晶質 との混相皮膜へ, さらに非晶質の皮膜へと移行していくこと が推察される。

これらの W 含有量の増加に伴う皮膜結晶性の移行変化と 図 5 に示しためっき内部応力の変化を対応させて考えると, めっき皮膜中の非晶質 (の体積比率の増加)がめっき内部応力 の増加に寄与している可能性が考えられる。すなわち, W が過飽和となる $31 \mathrm{wt} \% \mathrm{~W}$ 程度から $40 \mathrm{wt} \% \mathrm{~W}$ 前後まで(皮膜 中の非晶質の体積比率がほぼ $50 \%{ }^{26)}$ まで)の混相皮膜では W 含有量の増加と共に非晶質の寄与影響が現れ始め, めっき内 部応力の減少は次第に抑制された変化を示し, それ以上の $\mathrm{W}$ 含有量(皮膜中の非晶質の体積比率は $50 \%$ よりも大)の皮 膜では非晶質の寄与影響がさらに強くなり, めっき内部応力 は増加の変化に転じたことが推測される。また, $40 \mathrm{wt} \% \mathrm{~W}$ 前後の皮膜では, これらのめっき内部応力の減少と増加の変 化が相殺され，最小のめっき内部応力を示したと考えられる。 尚, 上記の $31 \mathrm{wt} \% \mathrm{~W}$ 程度から $40 \mathrm{wt} \% \mathrm{~W}$ 前後までの混相皮 膜におけるめっき内部応力の減少変化, 並びに非晶質による めっき内部応力の増加寄与の要因については, 本検討で明ら かに出来なかった。これらの明確化には, 例えば Watanabe ら ${ }^{27)}$ の示した多結晶体スケール領域での力学挙動再現モデ ルを応用し, 混相皮膜におけるめっき内部応力変化や非晶質 のめっき内部応力への寄与度を数值解析により推定する方法 が考えられる。この他, 各結晶性の皮膜に対し, その粒径や 共析水素など, 従来より議論されてきためっき内部応力発現 因子の作用を精査し, 考慮していくことも有効と考えられ, 今後の検討課題として進めたい。

以上のように, Ni-W 合金めっきの結晶性は, W 含有量が $31 \mathrm{wt} \% \mathrm{~W}$ 程度から, 結晶質と非晶質との混相, さらに非晶 質へと移行し，めっき内部応力の変化に影響を及ぼすことが 考えられた。また, 皮膜中の非晶質は, めっき内部応力の増 加に寄与している可能性が考えられ, その体積比率の大小が めっき内部応力の増減変化を引き起こしていることが推測さ れた。

\section{4. 結言}

工業利用上問題となり得る Ni-W 合金めっき皮膜のクラッ クについて, 各 $\mathrm{W}$ 含有量におけるクラック発生の挙動把握, さらにその発生要因と考えられるめっき内部応力の影響につ いて調査した。以下に知見を要約する。

1） Ni-W 合金めっき皮膜に発生するクラック数は, W 含有量 により変化した。クラック数は, $\mathrm{W}$ 含有量が 25 〜 $51 \mathrm{wt} \%$ の範囲において，40 $\mathrm{wt} \%$ 前後で極小数(クラックなし)と なる変化を示した。

2) Ni-W 合金めっきのめっき内部応力は, W 含有量が $40 \mathrm{wt} \%$ 前後で最小となる変化を示し, W 含有量による めっき皮膜のクラック数変化とほぼ一致した。めっき内部 応力の高い場合にクラックが発生しており, 両者の因果関 係が考えられた。

3） $\mathrm{Ni}-\mathrm{W}$ 合金めっきのめっき内部応力は, $30 \sim 46 \mathrm{wt} \% \mathrm{~W}$ の $\mathrm{W}$ 含有量範囲において, 全てめっき引張り応力が検出され, 
$\mathrm{W}$ 含有量に応じて大きく変化した。下地とのミスフィッ トの影響は小さく, W 含有量の変化に伴って, めっき皮 膜自体のめっき内部応力が変化しているものと考えられた。 4） Ni-W 合金めっきは, W 含有量の増加に伴い, 結晶質の皮 膜から非晶質との混相皮膜, さらに非晶質の皮膜へと移行 するが, 皮膜中に混在する非晶質がめっき内部応力の増減 変化に影響を及ぼすことが推測された。

(Received September 30, 2013 ; Accepted June 7, 2014)

\section{文献}

1 ) T. Morikawa, T. Nakade, Y. Sato, M. Yokoi, K. Ishida ; Hyomen Gijutsu, 50, 1169 (1999).

2 ) K. Itoh, F. Wang, T. Watanabe ; Bulletin of Tokyo Metropolitan Industrial Technology Research Institute, 6, 33 (2003).

3 ) T. Miyashige, R. Suzuki ; Kinzoku Hyomen Gijutsu, 22, 216 (1971).

4) T. Kudou, K. Mizuno ; Kinzoku Hyomen Gijutsu, 13, 162 (1962).

5 ) T. Omi, H. Takagi ; Hyomen Gijutsu, 40, 1432 (1989).

6 ) T. Omi, M. Nakamura, H. Yamamoto ; Kinzoku Hyomen Gijutsu, 39, 809 (1988)

7 ) N. Atanassov, K. Gencheva, M. Bratoeva ; Plat.and Surf.Fin., 84, 67 (1997).

8 ) T. Miyashige, R. Suzuki ; Kinzoku Hyomen Gijutsu, 22, 170 (1971).

9 ) M. Yasui, M. Takahashi, S. Kaneko, Y. Hirabayashi, K. Sugimoto, R. Maeda ; J.Surf.Finish.Soc.Jpn., 59, 667 (2008).

10）小濱＼cjkstart昭; 特開昭58-221298 (1983).
11) Y. Matsuda, H. Noguchi; Reports of Industrial Research Institute, Aichi Prefectural Government, 2, 40 (2003).

12) M. Itagaki, Y. Sakai, I. Shitanda, K. Watanabe, K. Yasuda ; J.Surf. Finish.Soc.Jpn., 59, 548 (2008)

13) T. Morikawa ; J.Surf.Finish.Soc.Jpn., 56, 308 (2005).

14) R.Weil ; Plating, 58, 137 (1971).

15) H. Ise ; Kinzoku Hyomen Gijutsu, 15, 19 (1964).

16) R. W. Hinton, L. H. Schwartz, J. B. Cohen ; J.Electrochem.Soc., 110, 103 (1963).

17）春山志郎 ; 表面技術者のための電気化学第2版, p.73およびp.143 (丸善(侏), 2005).

18) Y. Matsuda, J. Yoshino, H. Noguchi ; Reports of Industrial Research Institute, Aichi Prefectural Government, 1, 45 (2002).

19) H. Shiio, T. Shimizu ; Kinzoku Hyomen Gijutsu, 20, 105 (1969).

20）電気鍍金研究会編; めっき教本, p.82（日刊工業新聞社, 1986).

21) A. Brenner, S. Senderoff ; Proc.Am.Electroplaters'Soc., 35, 53 (1948).

22) A. Brenner, S. Senderoff ; Plating, 36, 810 (1949).

23) H. Alimadadi, M. Ahmadi, M. Aliofkhazraei, S. R. Younesi ; Materials and Design, 30, 1356 (2009).

24）春山志郎; 表面処理技術者のための電気化学第2版, p.144（丸善 (株), 2005).

25) K. Itoh, F. Wang, T. Watanabe ; J.Japan Inst.Metals, 65, 1023 (2001).

26) Y. Kimoto, A. Giga, T. Ohkubo, Y. Takigawa, K. Hono, K. Higashi ; Mater:Trans., 48, 996 (2007).

27) I. Watanabe, K. Terada, K. Matsui, M. Akiyama, A. Neishi ; J.Applied Mechanics, JSCE 6, 239 (2003) 